\title{
FEDERAL REGULATION OF FIREARMS SALES
}

The easy availability of firearms in the United States has become a matter of increasing Congressional concern. Hearings before two Senate committees $^{1}$ in 1963 and 1964 focused on abuses in the interstate sale of firearms by mail order. ${ }^{2}$ Public interest was especially aroused when a cheap mail order rifle was used to assassinate the President of the United States on November 22, 1963. At present several bills are pending in Congress to curb mail order sales of firearms to juveniles, criminals and other irresponsible persons.

Senator Dodd's bill ${ }^{3}$ would prohibit mail order sales to persons who are under eighteen years of age, who have been convicted of or are under indictment for a crime punishable by more than a year in prison, or who are forbidden by local law to receive or possess a firearm. It would continue to allow direct sales to other mail order purchasers, but only after the purchaser sends the seller an affidavit stating that he does not fall within the prohibited classes. The seller would be required to file a copy of this affidavit with the law enforcement authorities in the purchaser's community before shipping the firearm. Senator Scott's bills requires, instead of an affidavit, a certificate from the buyer's local law enforcement officer describing the buyer's criminal record, mental stability, and reputation for observance of law. The bills introduced by Representatives Lindsay ${ }^{5}$ and Karsten ${ }^{6}$ would outlaw the mail order gun business entirely by prohibiting the interstate shipment of firearms except between licensed manufacturers and dealers. All these bills are in the form of amendments to the Federal Firearms Act of 1938,? which presently makes it illegal for anyone who is a fugitive from justice or who

1 Hearings on S. Res. 63 Before the Subcommittee to Investigate Juvenile Delinquency of the Senate Committee on the Judiciary, 88th Cong., 1st Sess. (1963) [hereinafter cited as Judiciary Hearings]; Hearings on S. 1975 and S. 2345 before the Senate Committee on Commerce, 88th Cong., 1st Sess. (1964) [hereinafter cited as Commerce Hearings].

2 Postal regulations forbid the sending of pistols through the mails except between registered dealers; mail order weapons are most often delivered by Railway Express. Judiciary Hearings 3222 .

3 S. 1975, with amendments, 88th Cong., 1st Sess. (1963).

4 S. 2345, 88th Cong., 1st Sess. (1963).

5 H.R. 9757, 88th Cong., 2d Sess. (1964).

6 H.R. 9323, 88th Cong., 1st Sess. (1963).

752 Stat. 1250 (1938), as amended, 15 U.S.C. $\$ \$ 901-09$ (1958). 
has. been convicted of a crime punishable by more than one year in prison to receive a gun shipped in interstate commerce.

Objections to legislation regulating the sale or possession of firearms have taken two forms. It has been argued that the legislation is unconstitutional under the second amendment, or that it is impractical because it would merely harass the law abiding citizen while failing to disarm the criminal and the irresponsible. ${ }^{8}$ Opposed to this view is a widespread feeling that it should not be as easy as it is for undesirable or irresponsible elements to purchase deadly weapons that often have no conceivable sporting purpose. This comment will evaluate the two objections with respect to the pending bills and discuss whether even more far-reaching federal regulation of the right to possess and carry firearms is possible or desirable.

\section{The Constitutronal ObJection}

The second amendment provides:

A well-regulated Militia, being necessary to the security of a free State, the right of the people to keep and bear Arms, shall not be infringed.

This provision should present no obstacle to any of the bills.

As a matter of first impression, it would have been possible to read the second clause independently of the first-as granting each citizen a personal right to "keep and bear Arms" for the defense of his country, for resisting government tyranny, for protection from criminals or wild animals, for sport, or for any other reason. By this reading, if any restrictions on this right were tolerated at all, it would be only to the degree that the most basic constitutional liberties can be compromised when the public interest demands. Whatever the merits of this view, which has been urged by firearms enthusiasts, it has not been adopted in the federal courts. Their decisions have read the first clause of the amendment, with its reference to the "well-regulated Militia," as severely qualifying the scope of the right protected.

The early cases decided that the second amendment operates as a restriction only on the federal government, and does not grant a right protected against infringement by other individuals or by the states. ${ }^{9}$ The

8 See, e.g., "A Joint Resolution of the National Police Officers Association of America and the National Shooting Sports Foundation, Inc.," Judiciary Hearings 3504-05 "[R]estrictive antigun laws do not succeed in disarming the criminal, but do disarm the law-abiding citizen, thus denying the law-abiding citizen effective self-defense, as well as jeopardizing his opportunities for training in the use of firearms, and discouraging his hunting and gun sports afield. ..."

9 Presser v. Illinois, 116 U.S. 252, 265 (1886); United States v. Cruikshank, 92 U.S. (2 Otto) 542, 553 (1876). 
federal government made no attempt to regulate firearms until 1934, and then it utilized the taxing power. The National Firearms Act ${ }^{10}$ requires registration of all "firearms" (defined for purposes of the statute as including only machine guns, sawed-off shotguns or rifles, and silencers). Along with certain other taxes, it places a special tax of two hundred dollars on each transfer of such a firearm. In United States $v$. Miller, a federal district court held the tax invalid as an infringement of the right to bear arms, ${ }^{11}$ but on direct appeal the Supreme Court reversed.12 There was no showing that a sawed-off shotgun has "some reasonable relationship to the preservation or efficiency of a well regulated militia,"13 the court said, and so ownership of one could be made prohibitively expensive. Most of the opinion was devoted to describing from historical sources what Americans at the time of the adoption of the Constitution conceived a militia to be: evidently all the citizens prepared to assemble in time of emergency with their own weapons for the common defense. ${ }^{14}$

Assuming that the Court is correct in saying that such a militiaman would have no use for a sawed-off shotgun, it is hard to dispute that he might have a great deal of use for a machine gun. Yet the act has always been applied to machine guns, ${ }^{15}$ and its constitutionality now seems beyond dispute. Further, the Federal Firearms Act ${ }^{16}$ attempts to prevent the receipt of guns in interstate commerce by certain categories of people whether the guns are useful to the militia or not. It was alleged to be unconstitutional under the Miller test in Cases $v$. United States, ${ }^{17}$ but the First Circuit recognized that the Supreme Court could not have intended to imply that all regulation of weapons useful to the militia was unconstitutional.

The rule which it laid down was adequate to dispose of the case before it and that we think was as far as the Supreme Court intended to go. ... Another objection to the rule of the Miller case as a full and general statement is that according to it Congress would be prevented by the Second Amendment from regulating the possession or use by private persons not present

1048 Stat. 1236 (1934), as amended, 26 U.S.C. $\$ \S 5841-62$ (1958).

11 United States v. Miller, 26 F. Supp. 1002 (W.D. Ark. 1939).

12307 U.S. 174 (1939).

$13 \mathrm{Id}$. at 178.

14 Id. at 178-82.

15 See, e.g., Castro v. United States, 296 F.2d 540 (5th Cir. 1961). Sergeant K. T. Carpenter of the Los Angeles Police Dept. testified, "Since Congress passed the National Firearms Act of 1934, the syndicated hoodlums who infest our major cities have given up the machine gun as a tool of the trade." Judiciary Hearings 3255.

1652 Stat. 1250 (1938), as amended, 15 U.S.C. $\$ \S 901-09$ (1958).

17131 F.2d 916 (1st Cir. 1942). 
or prospective members of any military unit, of distinctly military arms, such as machine guns, trench mortars, anti-tank or anti-aircraft guns .... 18

The Third Circuit agreed, and its holding in United States v. Tot ${ }^{10}$ seems an accurate summary of present law:

One could hardly argue seriously that a limitation upon the privilege of possessing weapons was unconstitutional when applied to a mental patient of the maniac type. The same would be true if the possessor were a child of immature years. In the situation at bar Congress has prohibited the receipt of weapons from interstate transactions by persons who have previously, by due process of law, been shown to be agressors against society. Such a classification is entirely reasonable and does not infringe upon the preservation of the well-regulated militia protected by the Second Amendment. ${ }^{20}$

Miller, then, suggests that the "militia" will not be harmed by effectively outlawing sawed-off shotguns. Tot and Cases add that persons reasonably classified as unfit to possess weapons can be prevented from purchasing them without making the militia any less effective in guaranteeing "the security of a free State." It is not easy to determine just what the "militia" is that the acts do not harm. Courts have said what the militia is not, but never what it is. The Supreme Court has only described what it believes the eighteenth century conception of a militia to have been. The circuit courts clearly had in mind official military units.

But whatever the militia is, if Congress were to ban interstate mail order sales to individuals altogether as the Lindsay and Karsten bills provide, it is difficult to see how the militia could be harmed any more than by existing legislation. Anyone could still buy a gun locally; at most he would simply be required to deal face to face with the seller. Under any definition, the militia is not harmed when its members buy their guns in stores instead of by mail order. Of course these local sales will be subject to local regulation, but it has long been settled that the second amendment does not prohibit restrictions imposed by state and local governments. ${ }^{21}$

$18 \mathrm{Id}$. at 922 .

19131 F.2d 261 (3d Cir. 1942), rev'd on other grounds, 319 U.S. 463 (1943).

$20 \mathrm{Id}$. at 266-67.

21 Presser v. Illinois, 116 U.S. 252 (1886); cf. United States v. Cruikshank, 92 U.S. (2 Otto) 542 (1876). But there is dictum in Presser that the states may not enforce a prohibition of arms which would go so far as to "deprive the United States of their rightful resource for maintaining the public security, and disable the people from performing their duty to the general government." 116 U.S. at 265. 
If Congress could ban all direct mail order sales, then a fortiori it can ban some mail order sales without doing any more harm to the militia. The categories of people that are forbidden to purchase by mail order must be determined reasonably and fairly, but this is a problem under the fifth amendment, not the second. The second amendment would apparently allow even unfair categories so long as the effectiveness of the militia were not impaired.22

The view of the second amendment taken in Miller, Cases and Tot would in fact allow far more regulation of firearms than any of the mail order bills propose. Since nothing in those cases was held to harm the militia, a federal license, which could be denied to individuals reasonably and fairly. determined to be unfit for the privilege, might be required to purchase a firearm even locally. ${ }^{23}$ Similarly, Congress might use the taxing power to require that all guns be registered with the Internal Revenue Service as an aid to tracing weapons used in crime. ${ }^{24}$

Only if Congress were to attempt to disarm the entire population, or a large part of it, would a second amendment issue be squarely raised. Determining the constitutionality of such a radical and unlikely step would require a definition of what the militia is that the second amendment protects. It is conceivable that the Supreme Court might hold that the militia it discussed in United States $v$. Miller no longer exists in this age of military professionalism, and that therefore the second amendment protects nothing at all. On the other hand, it might say that a militia of private citizens armed with their own weapons is still necessary to the security of a free state, or is protected by the Constitution even if it is not. What the Court would do in such a predicament, however, can only be speculation, for Congress has shown no intention to take any action strong enough to raise constitutional doubts.

22 A prohibition of the sale of guns to red-heads could be so unreasonable that redheaded individuals would be denied due process of law, but it might not be so unreasonably broad as to unduly harm the militia. The second amendment goes only to the latter issue. See text accompanying note 20 supra.

23 Such regulation must, of course, be justified under the commerce power as well as under the second amendment, but it has been held that Congress can regulate local sales of goods which have previously been shipped in interstate commerce. See, e.g., United States v. Sullivan, 332 U.S. 689 (1948); United States v. 2600 State Drugs, 235 F.2d 913 (7th Cir. 1956).

24 Such a plan for national registration might be attacked on the theory that a centralized system could be used by a tyrannical government or foreign conqueror to locate and confiscate all firearms in private hands and thus to disarm the militia. A proponent of such an argument, however, would doubtless have a hard time convincing the courts that the danger to the militia is real and alarming enough to overbalance the legislature's determination of what the public safety requires. 


\section{Desirability and Effegtiveness of the Proposed Bilis}

The facts which led to the proposed curbing of the mail order gun business were developed at hearings before the Senate Commerce Committee and the Senate Judiciary Subcommittee to Investigate Juvenile Delinquency. Witnesses testified that under present law any juvenile, habitual criminal or homicidal maniac can obtain a pistol or other firearm simply by sending in his money in response to an advertisement. Magazine advertisements deliberately suggest that purchase of a ten or twenty dollar pistol will give one authority and power. ${ }^{25}$ They offer cheap weapons that are often unobtainable from sporting goods dealers because they have no legitimate sporting function.

All four bills seek to amend the Federal Firearms Act of 1938,28 which has largely failed in its objective of regulating interstate shipments of firearms. Briefly, this act now requires dealers and manufacturers of firearms to purchase licenses from the federal government for a fee of one dollar per year for dealers and twenty-five dollars per year for manufacturers. Persons convicted of or under indictment for crimes of violence punishable by a term of more than one year in prison, and fugitives from justice, are prohibited from shipping or receiving firearms in interstate commerce. Dealers may not ship firearms to anyone who they have reason to believe is such a person. Before a dealer can ship a firearm to any person other than another licensed dealer or manufacturer in any state which requires a license to purchase such a firearm, he must see the license. Stolen firearms may not be transported in interstate commerce. Complete records of sales must be kept. ${ }^{27}$ Violators of any of these sections can be punished by up to a two thousand dollar fine and five years in prison.

According to the Bureau of Prisons, the only defendants convicted in the federal courts in 1961 for violations of the Federal Firearms Act were felons who had transported firearms across state lines. ${ }^{28}$ Apparently no dealer has ever been convicted of sending a firearm to a person for-

25 The testimony of Sgt. K. T. Carpenter of the Los Angeles Police Dept., Judiciary Hearings 3188, 3192-3202, contains exhibits of advertisements. A typical advertisement has a drawing of one man pointing a pistol at another, with the caption "HALT! You'll speak with authorityl" Id. at 3195. Another has a photograph of a pistol next to a shot glass and a poker hand on a card table. A particular type of revolver was advertised as "so potent it was almost barred by the Geneva Convention." Judiciary Hearings 3366.

2652 Stat. 1250 (1938), as amended, 15 U.S.C. $\$ \S 901.09$ (1958).

27 Newspaper readers will recall the speed with which Lee Harvey Oswald's rifle was traced after the assassination of President Kennedy. This was made possible by the records kept by the mail order dealer under the Federal Firearms Act.

28 Judiciary Hearings 3375, (testimony of James V. Bennett, Director, U.S. Bureau of Prisons). 
bidden to receive it. ${ }^{29}$ There are several reasons why this is true. First, it has been impossible to prove that any dealer knew or had reason to know that any purchaser had been indicted for or convicted of a crime of violence, or was a fugitive from justice. The careful dealer simply asks his customers to certify that they are not such persons; he has no duty to make an investigation. Second, only seven states require a license to purchase a firearm; all other state laws deal with sale or possession. Third, anyone who pays the one dollar fee can become a "dealer" whether or not he is engaged in any business, and thus circumvent the state licensing law. Fourth, fly-by-night dealers find it easy to violate the state purchase license requirements by shipping guns in plain packages. Fifth, there is a thriving industry sending blank cartridge pistols into New York, which has a strict purchase license statute, where they are converted into serviceable weapons. Blank pistols are not covered by the act.

The bill introduced by Senator Dodd ${ }^{30}$ attempts to remedy the ineffectiveness of the Federal Firearms Act by tightening its restrictions. It raises the license fee to ten dollars for dealers and fifty dollars for manufacturers and pawn-brokers, in an attempt to restrict these classifications to persons doing a bona fide business in firearms. Applicants must be over twenty-one years, and not persons prohibited from receiving or shipping firearms. Dealers or manufacturers who ship by any carrier must give written notice to the carrier that the package contains a firearm, and the carrier must not deliver it to anyone it knows or has reasonable cause to believe is under eighteen years of age. The heart of the bill is its affidavit section. Before shipping a firearm to anyone but another licensed manufacturer or dealer, the vendor must receive a notarized affidavit in which the purchaser swears that he is over eighteen years, that he is not prohibited by the act from receiving the firearm, and that no laws of his locality would be violated by his receipt or possession of the frearm. The affidavit must also give the name and address of the principal law enforcement officer of the purchaser's locality, and the dealer must send a copy of it along with a description of the firearm to that official before making the shipment.

If properly enforced by the local officials, this measure should have some impact. Many purchasers will presumably be reluctant to make a false affidavit, especially since to do so violates the act as well as the applicable perjury laws. However, the bill has two major weaknesses.

First, it relies on local authorities to enforce federal law. If they do not have the resources or inclination to investigate the affidavits they

29 Ibid.

30 Supra note 3. 
receive and report violations to the United States Attorneys, juveniles and convicted felons will be able to violate the federal prohibitions with impunity. Federal investigative officials will not receive the affidavits. Given the limited objectives of the bill, however, this may not be as serious as it seems. Even if perfectly enforced, a mail order bill can have little practical impact in a community where local firearms sales are unregulated, because of over-the-counter selling. Communities which have strict regulation and enforcement of their own laws may be expected to help control the mail order traffic as well.

Second, purchasers may still circumvent the law by becoming dealers if they are over twenty-one and can put up ten dollars-still a very low amount. This procedure completely avoids the affidavit requirements. It is significant that no one has ever been prosecuted in at least one major metropolitan area for making a false statement in applying for a dealer license under the Federal Firearms Act. ${ }^{31}$ The fee for dealers should be raised to a sum high enough to discourage ordinary purchasers from obtaining the license; Rep. Karsten's figure of one hundred fifty dollars seems more realistic.

Senator Scott's bill ${ }^{32}$ requires the mail order purchaser to submit, instead of an affidavit, a certificate from his highest local law enforcement officer stating his purpose for buying the firearm, his criminal record, and any available information as to his "probable mental competence and stability," and his "reputation for observance of law." This requirement would be a considerable nuisance to the bona fide firearms dealer, who would have to obtain a new certificate for each purchase. Even as applied to individuals, it would be anathema to the shooting clubs and gun enthusiasts. Presumably the local law enforcement officer could prevent any purchase by refusing to give a certificate, and the terms of the bill might make him very cautious. He would be required either to make a careful investigation of each application or risk the embarrassment of "certifying" a murderer or lunatic. There is no provision for a fair hearing or appeal from an arbitrary judgment, which may raise problems of due process. This bill cures the problem of indiscriminate mail order sales, but at the price of giving arbitrary power to the police chief.

The easiest answer to the mail order problem is to outlaw the interstate mail order firearms business altogether. That is what Representatives Lindsay and Karsten propose. ${ }^{33}$ Only shipments between licensed

31 Judiciary Hearings 3220-21 (testimony of Sergeant K. T. Carpenter, Investigator, Los Angeles Police Dept.).

32 Supra note 4.

33 Supra notes 5 \& 6 . Rep. Karsten's bill differs from Rep. Lindsay's principally in that it goes so far as to make it illegal for an individual to take his own gun across 
dealers and manufacturers would be allowed. Violators could be apprehended easily because mail order sellers have to advertise to get business. The problems of local enforcement of federal law raised by the Dodd bill would no longer be present, and gun purchasers would not be greatly inconvenienced. One could still purchase the same firearms through any licensed dealer, or by mail order from any supplier within the state. And the public might benefit a great deal from restricting the sale of guns to local dealers, presumably primarily sporting goods stores. In deciding what to stock and to whom to sell, a store owner is likely to be influenced by public opinion and his own sense of community responsibility, as well as by direct pressure from the law. These advantages may well justify putting interstate mail order sellers out of business if the Dodd bill should prove ineffective.

In any event, Congress is not likely to pass any legislation stronger than the Dodd bill at this session. Firearms dealers and the rifle associations have considerable influence in Congress, and most of the witnesses before the committees, including the National Rifle Association, Senator Scott and Representative Lindsay, were willing to compromise and accept the Dodd Bill. It is a good step forward, and stricter measures can be considered if it fails in practice.

\section{Conclusion}

Even the most effective mail order legislation can do little to keep firearms out of irresponsible hands in a locality which allows anyone to purchase a gun with no questions asked. This would not be a cause for federal concern if local conditions had only local effect, but unfortunately firearms sold in one state may often cause tragedy in another. Local police officers, for example, have complained that the strict regulations of their communities were thwarted by out of state sales "over the counter" in addition to mail order sales. ${ }^{34}$

On the other hand, there is an excellent case for leaving the firearms problem principally to state and local control. The need to regulate guns in Chicago, where there is very little to shoot at except people, is far greater than in rural Montana. The same distinction can be drawn between urban and rural areas in the same state. Moreover, if the firearms laws of one state have effects in other states, so do inefficient police forces,

a state line unless he brings it back to its former location within ninety days. This raises the possibility that any man who moved from one state to another and took his hunting rifles along with him might be sentenced to a prison term, whether or not he knew the law.

34 Judiciary Hearings 3394, 3437 (statements of police officers from New York and the District of Columbia). 
ineffective prisons and practically everything else that relates to crime. Crime prevention and cure is still primarily left to the states and local communities, and to make it otherwise would be to effect a major overhaul of American government.

Among suggestions for future legislation is a national registration system to aid federal authorities in tracing weapons used in crimes. The problem is that such a system would work only if criminals could be induced to register their weapons or were amateurish enough to use weapons previously registered by someone else without obliterating the serial numbers. The expense and inconvenience of enforcing such a system could be justified only by major advances in law enforcement-a heavy burden of proof to meet.

On the other hand, state legislation prohibiting the sale of firearms to minors would probably be desirable. In the past, effective gun control laws have been difficult to pass at the state level. Undoubtedly this is due to the attitude of shooting sports associations that even the mildest laws may be the first step towards repressive measures that will disarm the honest citizen. But the testimony of National Rifle Association officials before the Senate Committees shows that this reaction is not inevitable. ${ }^{35}$ Prohibiting the sale of firearms to minors would extend the policy of the Dodd bill to all sales, and would be consistent with the National Rifle Association's policy that juveniles should use firearms only under adult supervision. Young people could still use firearms, but an adult would have to take the responsibility of ownership.

What the shooting groups resist, however, is any requirement that a license or police permit be required to purchase a firearm. They fear that police officers will be eager to deny such permission on trivial grounds to avoid any possibility of granting permission to the wrong person. This argument has force. Even if there is a possibility of administrative or judicial review, the inconvenience may be considerable. Only the lawful user would be frustrated, for it is hard to believe that criminals who want guns will have difficulty in purchasing them from illegal sources. Chicago Police Superintendent Orlando Wilson, for example, believes that gun licensing procedures are of little aid in law enforcement and cites the ineffectiveness of present laws against the carrying of concealed weapons as evidence that firearms regulation is no cure for crime. ${ }^{36}$

35 Judiciary Hearings 3467-68; Commerce Hearings 281 (testimony of Franklin L. Orth, executive vice-president of the N.R.A.).

36 Letter from $O$. W. Wilson to the University of Chicago Law Review, February 14, 1964. But see the testimony of James V. Bennett, Director of the U.S. Bureau of Prisons, Commerce Hearings 100 (citing statistics showing that the homicide rate is lower in cities with effective gun control laws than in cities without such laws). 
The one legal remedy that both the sports organizations and the police are eager to see adopted is mandatory long prison terms for persons convicted of carrying a firearm in the commission of a felony. But simply adding on penalties for crimes committed with firearms seems the most short-sighted proposal of all. This comment will not attempt to discuss whether harsh prison sentences in fact deter crime, but even assuming that premise, criminals certainly will not deterred from using guns or other deadly weapons in felonies unless they are convinced that they will receive a relatively light sentence for the felony and a heavier sentence for having the weapon. Unfortunately, sentencing standards so often vary from judge to judge that the criminal probably expects his sentence to depend on luck rather than on whether or not he carries a weapon. ${ }^{37}$

In short, it is frustrating that there is no easy way to keep firearms out of the hands of irresponsible or criminal elements. The problem, basically, is that we must choose between unpleasant alternatives. If the ordinary citizen who appears to be responsible and law-abiding is allowed to purchase and possess firearms, then it is unrealistic to suppose that those who want firearms for unlawful purposes will not be able to obtain them. Yet to prevent or discourage all the people from owning firearms would be politically impossible, difficult to enforce, and, conceivably, unconstitutional. Unless the American public is willing to pay a heavy price in "the right to keep and bear Arms," arms will likely continue to be misused.

37 See Bennett, $A$ Cool Look at "The Crime Crisis," Harper's Magazine, April 1964, p. 123. 